Available online on 15.02.2020 at http://jddtonline.info
Open Access to Pharmaceutical and Medical Research
unrestricted non-commercial use, provided the original work is properly cited

Open 2 Access

Research Article

\title{
Investigation of Renal Protective Effect of Euphorbia antiquorum L.(Stem) in Animal Model
}

\author{
Yadav Prashant Kumar*, Sisodia S. S. \\ Bhupal Nobles' College of Pharmacy, Faculty of Pharmacy, Bhupal Nobles' University, Udaipur, Rajasthan, India
}

\begin{abstract}
Introduction: Euphorbia antiquorum is a fleshy shrub belonging to the family Euphorbiaceae. It is widely distributed in the hotter parts of India. It is used as a substitute for the Ayurvedic drug 'Snuhee' whose accepted botanical source is Euphorbia neriifolia Linn. The leaf, stem, latex and root of Snuhee are used in treatment of diseases and conditions like, diabetes, coryza, and oedema. Objective: The present study is aimed to investigate the renal protective effect of E. antiquorum alcoholic extracts of the stem on alloxan (150mg/kg) induced diabetic Wistar rats. Methods: All animals were treated for 21 days and sacrificed on the last day. Unwanted placebo effect in case of the control group was blocked by executing appropriate vehicle treatment and same animal handling pattern. Extract and standard drug doses given orally were suspended in 0.9\% normal saline. Blood samples were drawn from retro orbital sinus using Diethyl-ether anesthesia at weekly intervals for 3 weeks. Blood samples were labeled in such a way that analysis team was kept blind about groups and nature of the study design. Body weight measurement and blood sampling were done on $1^{\text {st }}, 7^{\text {th }}, 14^{\text {th }}$ and $21^{\text {st }}$ day of the study. Conclusion: 21 days daily treatment with a test drug of ethanolic extract of stems of Euphorbia antiquorum significantly reduced the elevated Blood glucose level, Urinary Albumin, urine creatinine, serum creatinine in alloxan induced diabetic rats.
\end{abstract}

Keywords: Nephropathy, Glomerulonephritis, Creatinine, Albumin, Oedema

Article Info: Received 13 Nov 2019; Review Completed 04 Jan 2020; Accepted 12 Jan 2020; Available online 15 Feb 2020

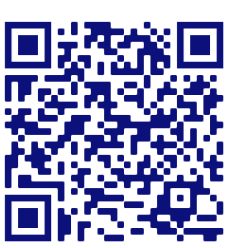

Cite this article as:

Yadav PK, Sisodia SS, Investigation of Renal Protective Effect of Euphorbia antiquorum L.(Stem) in Animal Model, Journal of Drug Delivery and Therapeutics. 2020; 10(1-s):39-44 http://dx.doi.org/10.22270/jddt.v10i1-s.3871

*Address for Correspondence:

Bhupal Nobles' College of Pharmacy, Faculty of Pharmacy, Bhupal Nobles' University, Udaipur, Rajasthan, India

\section{INTRODUCTION}

India as a country is blessed with a rich heritage of traditional medical systems along with rich biodiversity to accomplish the herbal needs, as therapeutic benefits administered by these traditional and alternative medical systems. The Indian systems of medicine are Ayurveda, Siddha and Unani, which use herbs and minerals in the formulations. India which use 15 agro-climatic zones, 4700 plant species of which 15000 are reported to have medicinal properties varying degrees.[1]

The various parts of Euphorbia antiquorum have been associated with a number of pharmacological activities which are Cytotoxic activity, Hepatoprotective and antioxidant activity, Insecticidal activity of Euphorbia antiquorum L., Anti-hyperglycaemic and Insilco Aldose reductase inhibitory activity (Amutha, et al., 2012) , Cancer , Anti-inflammatory and anti-arthritic activities. [2-7]

Diabetic nephropathy appears in patients with both type 1 and type 2 diabetes after five to 10 years of active diabetes, and is heralded by the onset of abnormal amounts of albumin in the urine, termed micro-albuminuria, defined as a urinary albumin excretion rate of $20-200 \mu \mathrm{g} / \mathrm{min}$ in a timed specimen, $30-300 \mathrm{mg} / 24$ hours, or an albumin to creatinine ratio of $30-300 \mathrm{~g}$ albumin $/ \mathrm{mg}$ creatinine on a morning spot urine test. The spot urine/creatinine ratio has been shown to have high sensitivity and specificity for urinary albumin excretion compared with a timed measurement of urinary albumin. ${ }^{[8]}$ Diabetes is the most common cause of kidney failure, accounting for nearly 44 percent of new cases. Even when diabetes is controlled, the disease can lead to chronic kidney disease (CKD) and kidney failure. Kidney failure is the final stage of chronic kidney disease. Nearly 24 million people in the United States have diabetes and nearly 180000 people are living with kidney failure as a result of diabetes. The prevalence of nephropathy in India was less $18.9 \%$ in Vellore, $5.5 \%$ in Chennai) when compared with the prevalence of $22.3 \%$ in Asian Indians in the UK. In chronic renal failure patients the prevalence of diabetic nephropathy was $30.3 \%$ followed by chronic interstitial nephritis $(23 \%)$ and chronic glomerulonephritis (17.7\%).[9]

Alloxan is most widely used in experimental diabetic research. Alloxan produces selective necrosis of the beta cells of pancreas. The alloxan is administered by various routes 
like intravenous, intraperitoneal and subcutaneous. Alloxan is used for induction of diabetes in experimental animals such as mice, rats, rabbits and dogs. The routes and dose of alloxan required may vary depending upon the animal species.[10-11]

\section{MATERIALS AND METHODS}

\subsection{Plant material}

Fresh stems of E. antiquorum were collected from the vicinity of Varansi district in Uttar Pradesh, India during the month of January, 2018 and air dried. The plant material was identified and authenticated by Prof. N. K. Dubey, Taxonomist, FNASc and FNAAS, Center of Advanced Study in Botany, Institute of Science, BHU, Varanasi, India. The voucher herbarium specimen (Euphorbia.2018/4) has been deposited in the Department of Botany.

\subsection{Animals}

All the animals used for the study were healthy and active in their cage. Studies were carried out using male Wistar rats weighing 170-200 g. The animals were bred, reared and housed in the animal house of BNU University with CPCSEA no. (03/BNCP/IAEC/2018). The rats were group housed in polyacrylic cages $(38 \times 23 \times 10 \mathrm{~cm})$ with not more than six animals per cage and maintained under standard laboratory conditions (temperature $25 \pm 2{ }^{\circ} \mathrm{C}$ ) and relative humidity $50 \%( \pm 10 \%)$, with a dark and light cycle of $12 \pm 1 \mathrm{~h}$. They were allowed free access to standard dry pellet diet (Amrut, India) and water ad libitum and kept in quarantine for a week to acclimatize with animal house facility(CPCSEA guideline,7th January, 2010). The animals were maintained in accordance with the guidelines specified by the Committee for the Purpose of Control and Supervision of Experiments on Animals (CPCSEA), Ministry of Environment and Forests (Animal Welfare Division), Govt of India, New Delhi.

\subsection{Preparation of extracts}

Coarsely powdered (200 g) stem was extracted with $95 \%$ (V/ V) alcohol in a soxhlet apparatus. The extract obtained was filtered and subjected to concentration at a temperature below 50oC to obtain a dark brown semi solid mass [yield $17.3 \%(\mathrm{~W} / \mathrm{W})]$. The extract was suspended in distilled water and used for further studies [12-13]

\subsection{Experimental design .}

Group-I (Normal or vehicle control): Group I animals were non diabetic and served as normal control and received $0.9 \%$ normal saline. Six healthy animals with moderate hyperglycemia, i.e. serum glucose between the normal ranges were randomly selected.

Group II (Diabetic control): Rats served as diabetic control, which were injected a single dose of $150 \mathrm{mg} / \mathrm{kg}$ b.w. of Alloxan monohydrate (ip) with $0.9 \%$ normal saline.

Group III: Diabetic rats were treated with ethanolic plant extract by gavages $(200 \mathrm{mg} / \mathrm{kg} /$ day b.w., p.o) in $0.9 \%$ normal saline once daily for 21 days.

Group IV: Diabetic rats were treated with ethanolic plant extract by gavages $(400 \mathrm{mg} / \mathrm{kg}$ b.w., p.o.) in $0.9 \%$ normal saline once daily for 21 days.

Group V: Which served as positive control, diabetic rats were treated with metformin by gavages $(200 \mathrm{mg} / \mathrm{kg} \mathrm{b.w.,}$ p.o.) in $0.9 \%$ normal saline once daily for 21 days.[14-15]

All animals were treated for 21 days and sacrificed on the last day. Unwanted placebo effect in case of each control group was blocked by executing appropriate vehicle treatment and same animal handling pattern. Extract and standard drug doses given orally were suspended in $0.9 \%$ normal saline. Blood samples were drawn from retro orbital sinus using diethyl-ether anesthesia after 3 weeks. Blood samples were labeled in such a way that analysis team was kept blind about groups and nature of study design. Body weight measurement and blood sampling were done on 21st day of the study. Animals (rats) were sacrificed, dissected and organs were cleaned and collected and kept in a suitable container.[16]

\section{RESULTS}

Table 3.1: Effect of Euphorbia antiquorum ethanolic extract on blood glucose level in alloxan induced diabetic rat.

\begin{tabular}{|c|c|c|c|c|c|c|}
\hline \multirow[t]{2}{*}{ Group } & \multirow[t]{2}{*}{ Treatment } & \multirow{2}{*}{$\begin{array}{l}\text { Dose } \\
\text { (mg/kg } \\
\text { b. w.) }\end{array}$} & \multicolumn{4}{|c|}{ Blood Glucose Level mg/dL (Mean \pm SEM) } \\
\hline & & & $1^{\text {st }}$ day & $7^{\text {th }}$ day & $14^{\text {th }}$ day & $21^{\text {st }}$ day \\
\hline 1 & NC & - & $115.5 \pm 3.030$ & $111.1 \pm 9.42$ & $110.6 \pm 8.25$ & $105.5 \pm 3.03$ \\
\hline 2 & DC & 150 & $122.6 \pm 25.31$ & $260.42 \pm 32.44$ & $281.22 \pm 36.27$ & $303.3 \pm 23.12$ \\
\hline 3 & $\mathrm{DC}+\mathrm{EAE}$ & 200 & $119.12 \pm 4.88^{*}$ & $202.44 \pm 7.49^{* *}$ & $229.47 \pm 8.28^{* *}$ & $244.54 \pm 11.76^{* * *}$ \\
\hline 4 & $\mathrm{DC}+\mathrm{EAE}$ & 400 & $118.70 \pm 4.52^{*}$ & $172.0 \pm 4.517^{* * *}$ & $198.0 \pm 4.517^{* * *}$ & $188.0 \pm 4.517^{* * *}$ \\
\hline 5 & DC+Metformin & 200 & $110.74 \pm 6.74^{*}$ & $131.5 \pm 8.44^{* * *}$ & $134.5 \pm 6.41^{* * *}$ & $128.8 \pm 4.55^{* * *}$ \\
\hline
\end{tabular}

Statistical significance test was done by ANOVA followed by Tukey's t test $(\mathrm{n}=6)$

Values are Mean \pm SEM of 6 animals per group, *Difference in blood glucose level of a group when compared with diabetic control significant at $\mathrm{p}<0.01$. ${ }^{* *}$ Difference in blood glucose level of a group when compared with diabetic control significant at $\mathrm{p}<0.05$. ${ }^{* * *}$ Difference in blood glucose level of a group when compared with diabetic control significant at $\mathrm{p}<0.001$. 


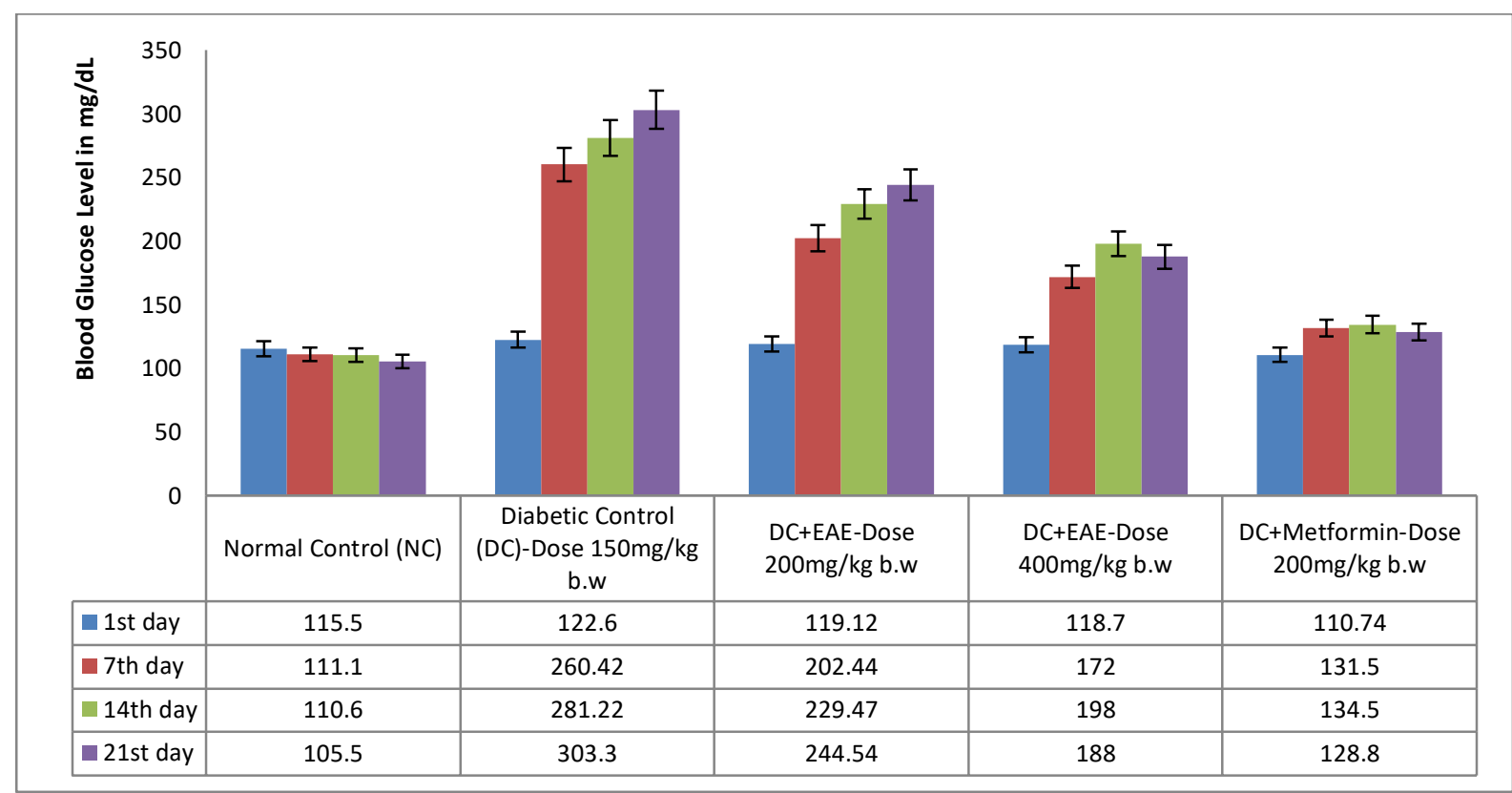

Figure 3.2: Effect of Euphorbia antiquorum ethanolic extract on blood glucose level in alloxan induced diabetic rat.

Table3.3: Effect of Euphorbia antiquorum ethanolic extract on creatinine urine in alloxan induced diabetic rat.

\begin{tabular}{|l|l|l|l|l|l|l|}
\hline Group & \multirow{2}{*}{ Treatment } & \multirow{2}{*}{$\begin{array}{l}\text { Dose } \\
(\mathbf{m g} / \mathbf{k g} \\
\mathbf{b . w .}\end{array}$} & & \multicolumn{4}{|c|}{ Creatinine Urine in mg/dL (Mean \pm SEM) } \\
\cline { 5 - 7 } & & & $\mathbf{1}^{\text {st }}$ day & $\mathbf{7}^{\text {th }}$ day & $\mathbf{1 4}^{\text {th }}$ day & $\mathbf{2 1}^{\text {st }}$ day \\
\hline 1 & & & & & & \\
\hline 2 & NC & - & $76.49 \pm 3.71$ & $79.22 \pm 4.23$ & $78.55 \pm 4.55$ & $74.88 \pm 5.14$ \\
\hline 3 & DC & 150 & $78.76 \pm 7.09$ & $84.44 \pm 6.44$ & $96.46 \pm 7.22$ & $99.28 \pm 8.43$ \\
\hline 4 & DC+EAE & 200 & $78.47 \pm 2.45^{*}$ & $84.01 \pm 4.88^{*}$ & $93.45 \pm 5.74^{*}$ & $95.77 \pm 4.58^{*}$ \\
\hline 5 & DC+EAE & 400 & $77.54 \pm 4.22^{*}$ & $81.32 \pm 5.53^{*}$ & $90.87 \pm 6.52^{* *}$ & $93.55 \pm 4.54^{* *}$ \\
\hline
\end{tabular}

Statistical significance test was done by ANOVA followed by Tukey's t test $(n=6)$

Values are Mean \pm SEM of 6 animals per group, *Difference in Creatinine Urine level of a group when compared with diabetic control significant at $\mathrm{p}<0.01$. ${ }^{*}$ Difference in Creatinine Urine level of a group when compared with diabetic control significant at $\mathrm{p}<0.05{ }^{* * *}$ Difference in Creatinine Urine level of a group when compared with diabetic control significant at $\mathrm{p}<0.001$.

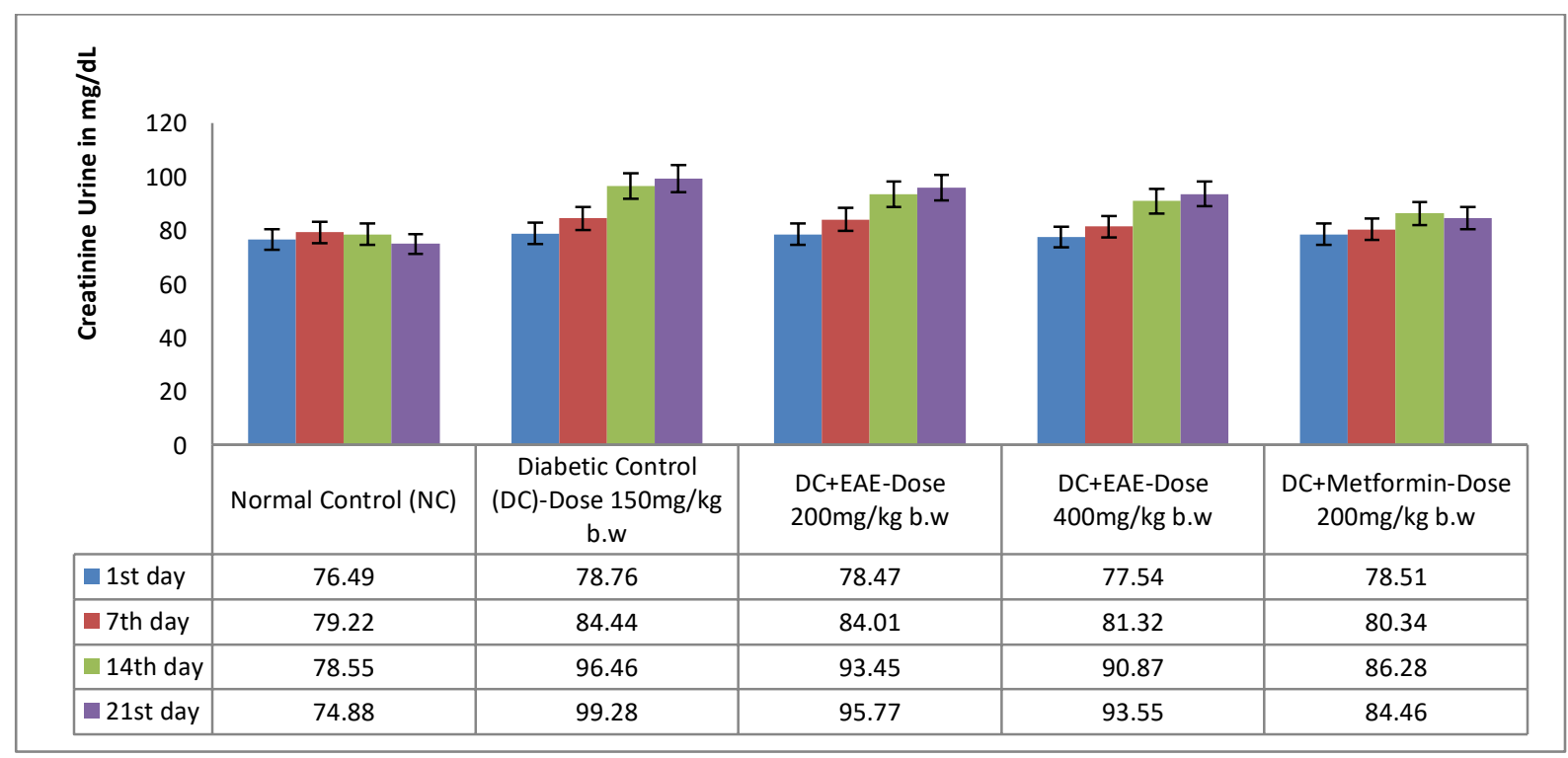

Figure 3.4: Effect of Euphorbia antiquorum ethanolic extract on creatinine urine in alloxan induced diabetic rat. 
Table 3.5: Effect of Euphorbia antiquorum ethanolic extract on Serum creatinine urine in alloxan induced diabetic rat.

\begin{tabular}{|c|c|c|c|c|c|c|}
\hline \multirow[t]{2}{*}{ Group } & \multirow[t]{2}{*}{ Treatment } & \multirow{2}{*}{$\begin{array}{l}\text { Dose } \\
\text { (mg/kg } \\
\text { b. w.) }\end{array}$} & \multicolumn{4}{|c|}{ Serum Creatinine Urine in $\mathrm{mg} / \mathrm{dL}$ (Mean \pm SEM) } \\
\hline & & & 1st day $^{\text {st }}$ & $7^{\text {th }}$ day & $14^{\text {th }}$ day & 21st day \\
\hline 1 & NC & - & $0.45 \pm 0.18$ & $0.42 \pm 0.11$ & $0.41 \pm 0.12$ & $0.39 \pm 0.06$ \\
\hline 2 & DC & 150 & $0.44 \pm 0.17$ & $0.79 \pm 0.34$ & $0.84 \pm 0.42$ & $1.48 \pm 0.67$ \\
\hline 3 & $\mathrm{DC}+\mathrm{EAE}$ & 200 & $0.46 \pm 0.11^{*}$ & $0.78 \pm 0.16^{*}$ & $0.83 \pm 0.16^{*}$ & $1.11 \pm 0.28^{* *}$ \\
\hline 4 & $\mathrm{DC}+\mathrm{EAE}$ & 400 & $0.48 \pm 0.12^{*}$ & $0.72 \pm 0.24^{* *}$ & $0.76 \pm 0.26^{* *}$ & $0.80 \pm 0.25^{* *}$ \\
\hline 5 & DC+Metformin & 200 & $0.46 \pm 0.06^{*}$ & $0.54 \pm 0.13^{* * *}$ & $0.67 \pm 0.16^{* * *}$ & $0.60 \pm 0.12^{* * *}$ \\
\hline
\end{tabular}

Statistical significance test was done by ANOVA followed by Tukey's t test $(n=6)$

Values are Mean \pm SEM of 6 animals per group, *Difference in serum creatinine urine level of a group when compared with diabetic control significant at $\mathrm{p}<0.01{ }^{* *}$ Difference in serum creatinine urine level of a group when compared with diabetic control significant at $\mathrm{p}<0.05 .{ }^{* * *}$ Difference in serum creatinine urine level of a group when compared with diabetic control significant at $\mathrm{p}<0.001$.

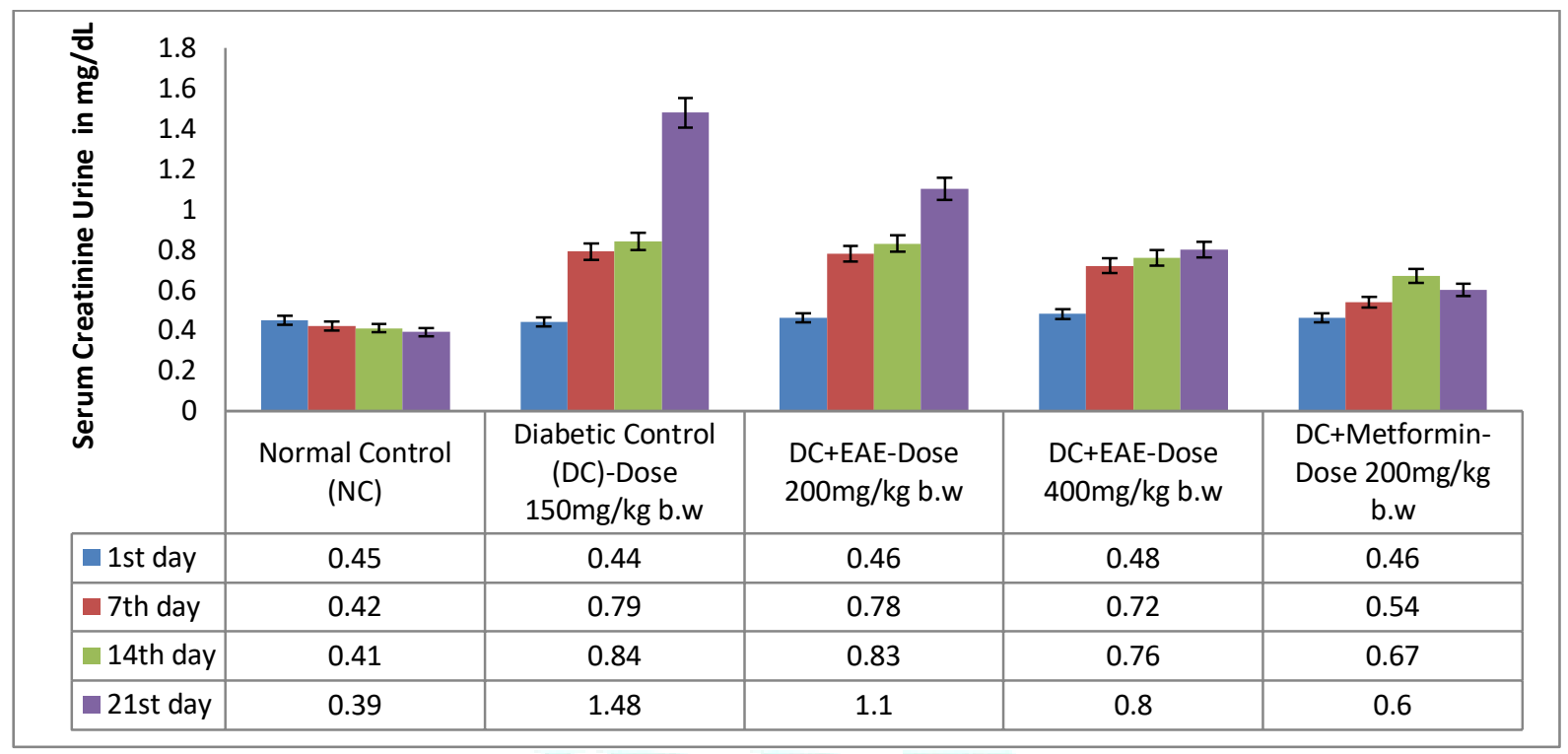

Figure 3.6: Effect of Euphorbia antiquorum ethanolic extract on Serum creatinine in alloxan induced diabetic rat.

Table 3.7: Effect of Euphorbia antiquorum ethanolic extract on Urinary Albumin in alloxan induced diabetic rat.

\begin{tabular}{|c|c|c|c|c|c|c|}
\hline \multirow[t]{2}{*}{ Group } & \multirow[t]{2}{*}{ Treatment } & \multirow{2}{*}{$\begin{array}{l}\text { Dose } \\
\text { (mg/kg } \\
\text { b.w.) }\end{array}$} & \multicolumn{4}{|c|}{ Urinary Albumin in mg/day (Mean \pm SEM) } \\
\hline & & & 1st day & $7^{\text {th }}$ day & 14th day & 21 st day \\
\hline 1 & NC & - & $1.50 \pm 0.07$ & $1.52 \pm 0.15$ & $1.54 \pm 0.12$ & $1.54 \pm 0.22$ \\
\hline 2 & DC & 150 & $1.55 \pm 0.19$ & $14.55 \pm 3.12$ & $23.55 \pm 3.21$ & $31.46 \pm 6.29$ \\
\hline 3 & $\mathrm{DC}+\mathrm{EAE}$ & 200 & $1.54 \pm 0.24^{*}$ & $13.21 \pm 1.13^{*}$ & $19.28 \pm 1.44^{* *}$ & $20.68 \pm 1.56^{* *}$ \\
\hline 4 & $\mathrm{DC}+\mathrm{EAE}$ & 400 & $1.52 \pm 0.34^{*}$ & $11.88 \pm 1.12^{* *}$ & $17.22 \pm 1.34^{* *}$ & $17.68 \pm 1.29 * * *$ \\
\hline 5 & DC+Metformin & 200 & $1.52 \pm 0.46^{*}$ & $10.43 \pm 1.28^{* * *}$ & $14.24 \pm 1.33^{* * *}$ & $11.43 \pm 1.24^{* * *}$ \\
\hline
\end{tabular}

Statistical significance test was done by ANOVA followed by Tukey's t test $(n=6)$

Values are Mean \pm SEM of 6 animals per group, *Difference in urinary albumin level of a group when compared with diabetic control significant at $\mathrm{p}<0.01$. ${ }^{* *}$ Difference in urinary albumin level of a group when compared with diabetic control significant at $\mathrm{p}<0.05$. ${ }^{* * *}$ Difference in urinary albumin level of a group when compared with diabetic control significant at $\mathrm{p}<0.001$. 


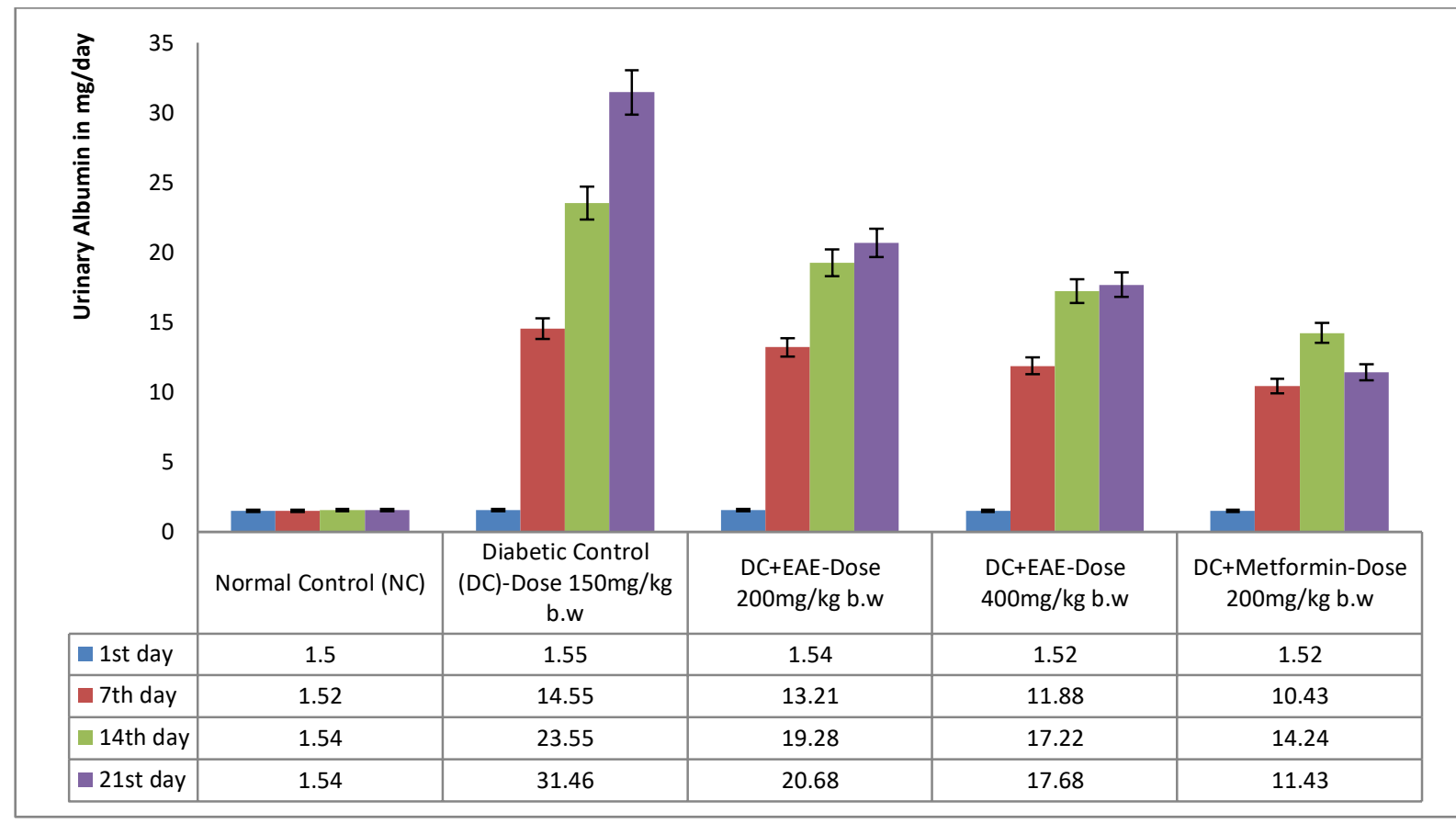

Figure 3.8: Effect of Euphorbia antiquorum ethanolic extract on Urinary Albumin in alloxan induced diabetic rat.

\section{DISCUSSION}

4.1. Effect of different doses of ethanolic extract of stems of Euphorbia antiquorum (EAE) and metformin on blood glucose level of alloxan-induced diabetic rat:

After administration of $7^{\text {th }}$ day of EAE at doses of $400 \mathrm{mg} / \mathrm{kg}$ b.w. (Group IV) significantly $(\mathrm{p}<0.05)$ reduced the blood glucose of alloxan-induced diabetic rats (Table 3.1 \& Figure 3.2), somewhat similar to what was seen in the standard (metformin) group (Group V) at a significant level $\mathrm{p}<0.001$. The animals of non-diabetic normal or vehicle control group (Group I) had fasting blood glucose levels of $115.5 \pm 3.030$ $\mathrm{mg} / \mathrm{dl}$ at day $1^{\text {st }}$ day and it was almost similar $(105.5 \pm 3.03$ $\mathrm{mg} / \mathrm{dl}$ ) on 21 st day, whereas that of diabetic control group was $122.6 \pm 25.31 \mathrm{mg} / \mathrm{dl}$ on $1^{\text {st }}$ day and gradually increased and reach up to $303.3 \pm 23.12 \mathrm{mg} / \mathrm{dl}$ (Group II) on $21^{\text {st }}$ day. The treated group with EAE at doses of $200 \mathrm{mg} / \mathrm{kg}$ b.w. (Group III) showed significant $(\mathrm{p}<0.05)$ reduction of blood glucose levels of $119.12 \pm 4.88 \mathrm{mg} / \mathrm{dL}$ on $1^{\text {st }}$ day to $244.54 \pm 11.76 \mathrm{mg} / \mathrm{dl}$ ( $^{* *} p<0.05$ vs. diabetic control group) at day of 21 . At the day 21 the doses of EAE at doses of 400 $\mathrm{mg} / \mathrm{kg}$ b.w. (Group IV) significantly reduced blood glucose levels to $188.0 \pm 4.517 \mathrm{mg} / \mathrm{dl}\left({ }^{* *} p<0.05\right.$ vs. diabetic control group).

\subsection{Effect of different doses of ethanolic extract of stems} of Euphorbia antiquorum (EAE) and metformin on urine creatinine level of alloxan-induced diabetic rat:

EAE at doses of $200 \& 400 \mathrm{mg} / \mathrm{kg}$ b.w. (Group IV) significantly reduced the urine creatinine level of alloxaninduced diabetic rats (Table 3.3 \& Figure 3.4), similar to what was seen in the standard (metformin) group (Group V). The animals of non-diabetic normal or vehicle control group (Group I) had urine creatinine level of $74.88 \pm 5.14 \mathrm{mg} / \mathrm{dl}$ at day 21, whereas that of diabetic control group was $99.28 \pm 8.43 \mathrm{mg} / \mathrm{dl}$ (Group II). The group treated with EAE at doses of $200 \mathrm{mg} / \mathrm{kg}$ b.w. (Group III) showed significant reduction of urine creatinine level of $95.77 \pm 4.58 \mathrm{mg} / \mathrm{dl}\left(^{*} p<\right.$ 0.01 vs. diabetic control group) at day of 21 . At the day 21 the doses of EAE at doses of $400 \mathrm{mg} / \mathrm{kg}$ b.w. (Group IV) significantly reduced urine creatinine level to
$93.55 \pm 4.54 \mathrm{mg} / \mathrm{dl}\left({ }^{*} p<0.01\right.$ vs. diabetic control group). The urine creatinine level of EAE at doses of $400 \mathrm{mg} / \mathrm{kg}$ b.w. (Group IV) demonstrated a notable significant decline to $93.55 \pm 4.54 \mathrm{mg} / \mathrm{dl}\left({ }^{*} p<0.01\right.$ vs. diabetic control group) but which is not even better than metformin $(200 \mathrm{mg} / \mathrm{Kg}$ b.w $)$ treated group (Group V) that reduced urine creatinine level to $84.46 \pm 6.23 \mathrm{mg} / \mathrm{dl}\left({ }^{*} p<0.001\right.$ vs. diabetic control group) at day of 21 .

4.3. Effect of different doses of ethanolic extract of stems of Euphorbia antiquorum (EAE) and metformin on serum creatinine level of alloxan-induced diabetic rat:

EAE at doses of $200 \& 400 \mathrm{mg} / \mathrm{kg}$ b.w. (Group IV) significantly reduced the serum creatinine level of alloxaninduced diabetic rats (Table $3.5 \&$ Figure 3.6), similar to what was seen in the standard (metformin) group (Group V). The animals of non-diabetic normal or vehicle control group (Group I) had serum creatinine level of $0.39 \pm 0.06 \mathrm{mg} / \mathrm{dl}$ at day 21, whereas that of diabetic control group was $1.48 \pm 0.67 \mathrm{mg} / \mathrm{dl}$ (Group II). The group treated with EAE at doses of $200 \mathrm{mg} / \mathrm{kg}$ b.w. (Group III) showed significant reduction of serum creatinine level of $1.11 \pm 0.28 \mathrm{mg} / \mathrm{dl}\left({ }^{*} p<\right.$ 0.01 vs. diabetic control group) at day of 21 . At the day 21 the doses of EAE at doses of $400 \mathrm{mg} / \mathrm{kg} \mathrm{b.w}$. (Group IV) significantly reduced serum creatinine level to $0.80 \pm 0.25 \mathrm{mg} / \mathrm{dl}\left({ }^{*} p<0.05\right.$ vs. diabetic control group). The serum creatinine level of EAE at doses of $400 \mathrm{mg} / \mathrm{kg}$ b.w. (Group IV) demonstrated a notable significant decline to $0.80 \pm 0.25 \mathrm{mg} / \mathrm{dl}\left({ }^{*} p<0.05\right.$ vs. diabetic control group) but which is not even better than metformin (200 mg/Kg b.w treated group (Group V) that reduced serum creatinine level to $0.60 \pm 0.12 \mathrm{mg} / \mathrm{dl}\left({ }^{* * *} p<0.001\right.$ vs. diabetic control group) at day of 21 .

4.4. Effect of different doses of ethanolic extract of stems of Euphorbia antiquorum (EAE) and metformin on urinary albumin level of alloxan-induced diabetic rat:

EAE at doses of $200 \& 400 \mathrm{mg} / \mathrm{kg}$ b.w. (Group IV) significantly reduced the urinary albumin level of alloxaninduced diabetic rats (Table $3.7 \&$ Figure 3.8), similar to what was seen in the standard (metformin) group (Group V). 
The animals of non-diabetic normal or vehicle control group (Group I) had urinary albumin level of $1.54 \pm 0.22 \mathrm{mg} / \mathrm{dl}$ at day 21, whereas that of diabetic control group was $3.14 \pm 0.69 \mathrm{mg} / \mathrm{dl}$ (Group II). The group treated with EAE at doses of $200 \mathrm{mg} / \mathrm{kg}$ b.w. (Group III) showed significant reduction of urinary albumin level of $2.99 \pm 0.83 \mathrm{mg} / \mathrm{dl}\left({ }^{* * *} p<\right.$ 0.01 vs. diabetic control group) at day of 21 . At the day 21 the doses of EAE at doses of $400 \mathrm{mg} / \mathrm{kg} \mathrm{b.w}$. (Group IV) significantly reduced urinary albumin level to $1.87 \pm 0.79 \mathrm{mg} / \mathrm{dl}\left(^{* * *} p<0.001\right.$ vs. diabetic control group). The urinary albumin level of EAE at doses of $400 \mathrm{mg} / \mathrm{kg}$ b.w. (Group IV) demonstrated a notable significant decline to $1.87 \pm 0.79 \mathrm{mg} / \mathrm{dl}$ ( ${ }^{* * *} p<0.001$ vs. diabetic control group) but which is not even better than metformin $(200 \mathrm{mg} / \mathrm{Kg}$ b.w $)$ treated group (Group V) that reduced urinary albumin level to $1.62 \pm 0.24 \mathrm{mg} / \mathrm{dl}\left({ }^{* * *} p<0.001\right.$ vs. diabetic control group) at day of 21 .

\section{CONCLUSION}

According to the standard working protocol, 21 days daily treatment with a test drug of ethanolic extract of stems of Euphorbia antiquorum significantly reduced the elevated Urinary Albumin, urine creatinine, serum creatinine in alloxan induced diabetic rats. Euphorbia antiquorum with oral hypoglycemic agents may be a valuable adjutant therapy to achieve and/or maintain glycemic control and possibly reduce or delay the onset of diabetic complications. Thus, these results offer scientific validation of ethanolic extract of stems of Euphorbia antiquorum in the management of diabetes mellitus in time-honored medicine system of India. Further studies will be carried out in future to identify the active antidiabetic principles of this plant that are responsible. It can be thereby suggested further for the investigations on humans to study the harmonizing effect of the amalgamation of ethanolic extract of stems of Euphorbia antiquorum and metformin on other body tissues.

\section{REFERENCES}

1. Johnson D.B, Raj A, Venkatanarayan R. Antidiabetic activity and toxicity studies of ethanolic extract of Polialthia longifolia roots. Research Journal of Pharmacy and Technology.2007; 10(5):1305-1312.

2. Devaliya R, Shirsat M. A Review on Indigenous Medicinal Plants for Diabetes Mellitus. Research Journal of Pharmacy and Technology.2017; 10(8):2828-2836.
3. Kharroubi AT, Darwish HM. Diabetes mellitus: The epidemic of the century. World Journal of Diabetes. 2015; 6(6):850-867.

4. Sumathi S, Malathy N, Dharani B, Sivaprabha J, Hamsa D, Radha P, Padma P.R. Cytotoxic Studies of Latex of Euphorbia antiquorum In Vitro Models. Journal of Medicinal Plants Research.2011; 5:4715-4720.

5. Jyothi T.M, Prabhu K, Jayachandran E, Lakshminarasu S, Ramachandra S.S. Hepatoprotective and antioxidant activity of Euphorbia antiquorum. Pharmacognosy Magazine.2008; 4:127-33.

6. De Silva W, Manuweera G, Karunaratne S. Insecticidal activity of Euphorbia antiquorum L. latex and its preliminary chemical analysis. The Journal of the National Science Foundation of Sri Lanka. 2008; 36(1):15-23.

7. Amutha P, Kumar N, Jayakumar P, Karthikeyan R. A study of Anti-hyperglycemic and insilico Aldose reductase inhibitory effect of terpenoids of Euphorbia antiquorum Linn. in alloxan induced diabetic rats. Indian Journal of Drugs and Diseases. 2012; 1(1):173-169.

8. Wen T.H; Hui Y L, Jou H.C, Yueh H.K, Ming J.F, Jing G.C. Latex of Euphorbia Antiquorum Induces Apoptosis in Human Cervical Cancer Cells via c-Jun N-terminal Kinase Activation and Reactive Oxygen Species Production. Nutrition and Cancer, 2012; 63(4):1339-1347.

9. Anand N.H, Ashok D.T, Kishor V.O, Ravindra, V.K, Rajkumar V.S. Anti-inflammatory and anti-arthritic potential of aqueous and alcoholic extracts of Euphorbia antiquorum. Pharmacology Online. 2011; 2:287-298.

10. Young BA, Pharmacologic Treatment of Diabetic Nephropathy, US Endocrinology, 2005; (1):43-5.

11. Kumar E.K, Janardhana G.R, Antidiabetic activity of alcoholic stem extract of Nervilia plicata in streptozotocin-nicotinamide induced type 2 diabetic rats. Journal of Ethnopharmacol. 2011; 133: 480-483.

12. Iranloye BO, Arikawe AP, Rotimi G, Sogbade AO., Anti-diabetic and antioxidant effects of Zingiber officinale on alloxaninduced and insulin-resistant diabetic male rats. Nigerian Journal of physiological Science. 2011; 26: 89-96.

13. Federiuk IF, Casey HM, Quinn MJ, Wood MD, Ward WK., Induction of type-1 diabetes mellitus in laboratory rats by use of alloxan: route of administration, pitfalls, and insulin treatment. Comparative Medicine. 2004; 54: 252-257.

14. CPCSEA Guidelines for Laboratory Animal Facility" published by CPCSEA and available at https://www.aaalac.org/resources/SOP_CPCSEA.pdf

15. Maithili V, Dhanabal SP, Mahendran S, Vadivelan R. Antidiabetic activity of ethanolic extract of tubers of Dioscorea alata in alloxan induced diabetic rats. Indian Journal of Pharmacology. 2011; 43:455-59.

16. Nagappa AN, Thakurdesai PA, Venkat Rao N, Singh J. Antidiabetic activity of Terminalia catappa Linn fruits. Journal of Ethnopharmacology. 2003; 88:45-50. 